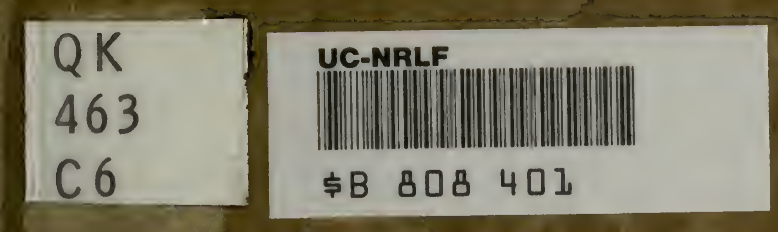

New Zealand plants suitahle for

North American gardens.

Cockayne, Leonard 


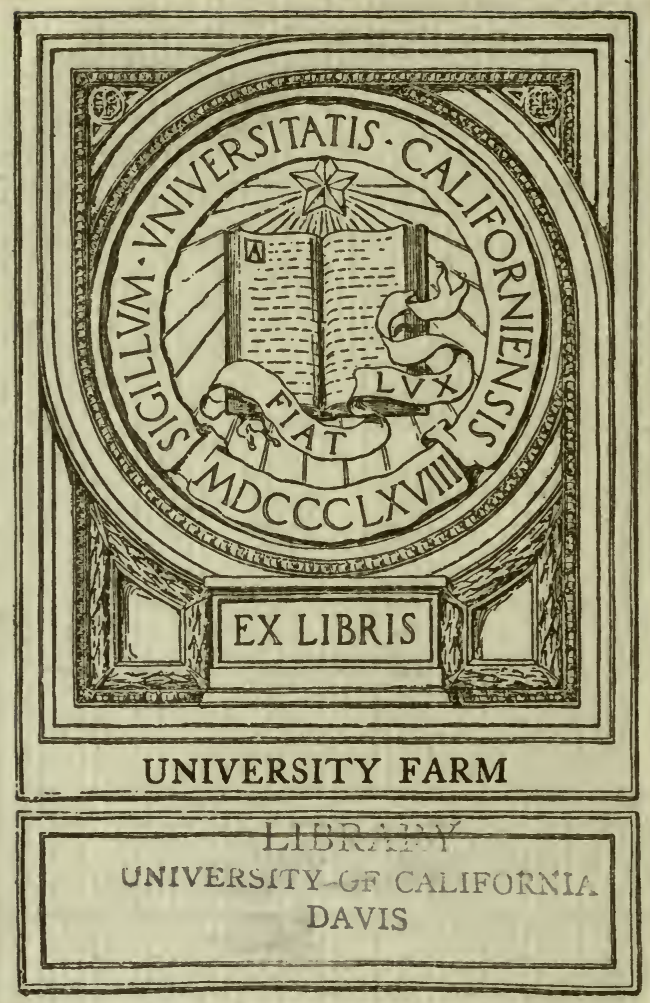




\section{NEW ZEALANd Plants}

SUITABLE FOR

NORTH AMERICAN GARDENS.

By

Dr. L. COCKAYNE, F.R.S.

PANAMA PACIFIC INTERNATIONAL EXPOSITION, SAN FRANCISCO, U.S.A.

February-December, 1915.

WELLINGTON, N.Z.

B) AUTHORITY. JOHN MACKAY, GOVERNMENT PRINTER.

$19 I_{4}$. 



\section{New Zealand Plants}

SUITABLE FOR

\section{NORTH AMERICAN GARDENS.}

By

Dr. L. COCKAYNE, F.R.S.

PANAMA PACIFIC INTERNATIONAL EXPOSITION, SAN FRANCISC0, U.S.A.

February-December, 1915.

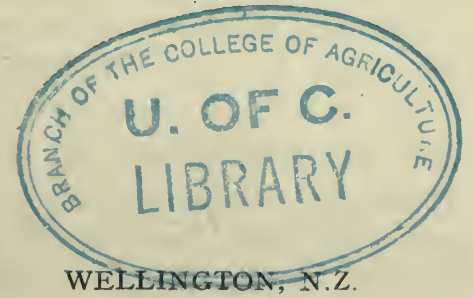

BY AUTHORITY: JOHN MACKAY, GOVERNMENT PRINTER

$$
1914 \text {. }
$$


Digitized by the Internet Archive in 2007 with funding from Microsoft Corporation 


\title{
NeW ZEaland Plants
}

SUITABLE FOR

\section{NORTH AMERIGAN GARDENS, WITH HINTS AS TO THEIR CULTIVATION.}

\author{
By Dr. L. Cockayne, F.R.S.
}

THE flora of New Zealand is altogether different from that of North America, or indeed any part of the North Temperate Zone, whence come so many hardy garden plants. Nor are its southern relationships strongly in evidence when we consider that nearly 80 per cent. of the flowering-plants are peculiar to the region. Further, though many of the families, and even genera, are identical with those of the Northern Hemisphere, some of their species appear in unwonted guise and with habits quite unexpected. Thus, several families which in North America occur as herbs merely-e.g., the aster, lily, violet, and fig-wort families-are represented in New Zealand by veritable shrubs or even trees. The species of blackberry (Rubus) are generally high climbing-plants, with stems perhaps as thick as one's arm. The conifers are related not to the pines, but to the yews, and one is so lowly as to form dense mats upon the ground. There is a buttercup (Ranunculus Lyallii) with great shield-shaped leaves and abundant pure-white blossoms $2-3$ in. in diameter raised on a stem $3 \mathrm{ft}$. high or more. A forget-me-not with leaves not unlike those of rhubarb, and with numerous blue flowers each $\frac{1}{2}$ in. across, is also remarkable. On the high mountains, certain plants of the aster family construct those immense compact cushions known as "vegetable sheep." The varied climates that New Zealand offers, its great topographical diversity, the lofty mountains, the extensive coastline, the many isolated islands - all these factors, together with the 
remarkable geological history, have contributed to evoke that great diversity of form which is exhibited by the species of the larger genera.

From the above it follows that the New Zealand flora has abundance of novelties to offer for garden purposes, while no few of the plants are strikingly different to those familiar to gardeners in general. Unfortunately, many of the species can tolerate but little frost; still, so far as the United States is concerned, the whole of the Pacific coast is suitable for the open-air culture of many New Zealand plants, as also any other area where the temperature does not fall below $15^{\circ} \mathrm{F}$., and where the rainfall is sufficient for everyday gardening operations. Also, in those States where the wintercold is severe many species may be grown in pots which, kept in a frost-proof greenhouse during the winter, can in the summer be used for ornamental purposes in the open borders or the rock-garden. The plants themselves differ greatly in their frost-tolerating capacities. In this pamphlet those only able to endure a degree or two are styled "half-hardy," while those not damaged by $x 6^{\circ}$ are considered "hardy." What intensity of cold is detrimental to the hardier of the high mountain species is not yet fully known, but it is evident that many of these should far exceed the $16^{\circ}$ limit.

All the species mentioned below can be raised from seed, provided it is absolutely fresh. The seed should be sown in porous soil in pots, pans, or boxes. Small seeds require to be covered with hardly any soil. Some species-e.g., Pittosporum and Sophora-germinate very slowly.

Living plants can be readily shipped from New Zealand. If small, they travel fairly well by parcels-post. Larger consignments should be sent in Wardian cases, such to be kept on deck. These cases need not be of elaborate construction. Abundance of moist Sphagnum moss should be tightly packed round the roots of the plants.

With regard to the names of species it must be pointed out that in a good many instances the name does not refer to a group of comparatively invariable individuals, but that several plants, quite distinct in appearance, may bear the same name. For instance, the name Veronica pinguitolia is 
impartially applied to possibly twenty plants, each of which for garden purposes is quite distinct. From this it follows that from packets of seed bearing a particular name quite a number of different plants may appear, some of which might be desirable acquisitions.

\section{TALL EVERGREEN TREES.}

Speaking generally, most of the tall trees grow only under forest conditions, and consequently a good many will not thrive in the open. Also, the majority are of such slow growth that, unless ornamental at an early age, they are not suitable for ordinary garden purposes. Tre following, however, will succeed under the common garden conditions unless the contrary be stated :-

\section{(1.) Agathis australis (Kauri).}

The young trees of this celebrated pine are of a pleasing pyramidal form. The species will thrive in a poor soil and a fairly dry climate. Though restricted to the warmest part of the North Island, the kauri can tolerate about $16^{\circ} \mathrm{F}$. of frost.

\section{(2.) Alectryon excelsum (Titoki, New Zealand Ash).}

A handsome tree, 30-6o ft. high, with pinnate leaves 4-I2 in. long. It is especially ornamental when bearing in abundance its large jet-black seeds half-hidden in their bright scarlet fleshy cups. It is barely hardy.

\section{(3.) Dacrydium cupressinum (Rimu, Red-pine).}

The young plants with their drooping foliage and graceful habit make admirable pot-plants for decorative purposes. Out-of-doors the rimu can only be grown in a moist, sheltered, shady position.

\section{(4.) Dacrydium Kirkii (Monoao).}

The adult resembles a cypress and the juvenile a silverfir. The latter attains a height of $30 \mathrm{ft}$. before suddenly changing its form. It is most elegant with its slender pyramidal habit, leafy to the base, and shining green leaves. The species is half-hardy. 
(5.) Knightia excelsa (Rewarewa, New Zealand Honeysuckle).

A half-hardy tall tree with thick narrow-oblong leaves 4 in. or more long, and rather showy dull-crimson flowers. It resembles in habit the Lombardy poplar. The juvenile form has much longer and narrower leaves. It succeeds in fairly dry soil.

\section{(6.) The Species of Metrosideros.}

$M$. tomentosa (the Pohutukawa or Christmas-tree) varies from a shrub to a tall tree, according to its position. It is a most important garden plant both on account of its intrinsic beauty and because it can be grown in the poorest soil, exposed to high winds or even sea-spray. When in bloom it is a magnificent object with its profusion of crimson flowers. It is only half-hardy.

$M$. robusta (the northern rata) is somewhat similar to the last described tree, but requires a more sheltered position. $M$. lucida (the southern rata) is far hardier than either, but it demands a moist climate, cool in summer. All the species can bloom when merely shrubs.

\section{(7.) The Species of Nothofagus (Southern Beech).}

Nothofagus is confined to New Zealand, southern South America, Tasmania, and eastern Australia, but the genus is closely related to the northern Fagus.

$N$. fusca (the red southern beech) and $N$. Solanderi (the black southern beech) are the easiest to cultivate. N. Menziesii (the silver southern beech) succeeds better in a rather moister climate. All the species are beautiful hardy trees. The reddish foliage of the young $N$. fusca is highly decorative.

\section{(8.) Phyllocladus trichomanoides (Tanekaha, Celery-leaved Pine).}

This truly remarkable tree possesses flattened fern-like branchlets which function as and exactly resemble leaves. It is fairly hardy. $P$. alpinus may be mentioned here, though it is only a low tree or a shrub. Its "leaves" are less deeply cut than those of the above. It is quite hardy. 


\section{(9.) The Species of Podocarpus.}

Podocarpus totara and $P$. Hallii, both called totara, are closely allied species, the one with thick furrowed bark, and the other with the bark much thinner. Both are easily cultivated and can be grown in dry ground. They can be readily raised from cuttings. The wood is extremely durable. Both species are hardy. The yew-like foliage has a dull-brown tint.

Podocarpus ferrugineus (the miro) in its juvenile stage makes a handsome fern-like pot-plant. In the open it requires a moist climate and shady position.

\section{(10.) Vitex lucens (Puriri).}

An extremely ornamental half-hardy tree with spreading branches, 3--5-foliate beautiful dark-green glossy leaves 3-5 in. long, and abundant pink blossoms. The timber is extremely durable.

\section{(11.) The Species of Weinmannia.}

There are two closely related species of Weinmannia, $W$. sylvicola (the tawhero) and $W$. racemosa (the kamahi). The last-named is the hardier. It has thick oblong-ovate leaves. I- 3 in. long, and bears in short racemes numerous flowers tinged with rose. Both species may bloom when comparatively small. $W$. sylvicola, in the juvenile stage, is very striking with its long yellowish-green pinnate leaves and dark bark.

\section{SMALL EVERGREEN TREES.}

\section{(1.) Ackama rosaefolia (Makamaka).}

A pleasing half-hardy tree, $20-40 \mathrm{ft}$. high, somewhat resembling the mountain-ash, bearing abundant bright yellowishgreen pinnate toothed leaves $3-8$ in. long. It prefers a rather rich soil.

\section{(2.) Ascarina lucida.}

An extremely handsome half-hardy tree or tall shrub, distinguished by its masses of beautiful glossy dark-green, more or less oblong, toothed leaves $\mathrm{I}-2$ in. long. It requires shade. 


\section{(3.) The Species of Brachyglottis (Rangiora).}

Brachyglottis, although ligneous, is related to the groundsels. There are two species, both half-hardy, closely resembling one another: $B$. repanda and $B$. rangiora, this latter distinguished by its larger leaves. Both species are exceedingly showy with their spreading habit, great oblong leaves 6-12 in. or more long, which are dull-green above but beneath milk-white through the dense mat of hairs which covers them. When in flower the huge panicles, bearing countless tiny sweetscented creamy flower-heads, render the plant eminently attractive.

\section{(4.) Carpodetus serratus (Putaputawheta, New Zealand Haw- thorn).}

The genus is found only in New Zealand, and contains but the one species. This is either a hardy tree or shrub having small ovate-oblong toothed leaves I-2 in. long, and bearing its small white flowers in pleasing abundance. It requires rather good soil and a fairly moist climate.

\section{(5.) The Species of Coprosma.}

Coprosma is one of the most characteristic genera in New Zealand, and contains both trees and shrubs. The trees most worthy of cultivation are: C. Baueri (half-hardy), distinguished by its glossy, more or less oblong leaves and orange-yellow drupes; C. chathamica (half-hardy), much resembling C. Baueri; C. robusta (hardy); C. arborea (half-hardy), with yellowishgreen ovate-spathulate leaves $\mathrm{I}-2$ in. long; and $C$. linariifolia (hardy), its leaves linear and about $\mathrm{I}$ in. long. C. Baueri is a splendid hedge-plant, and will tolerate sea-spray and violent wind. There are also variegated forms which when trained against a wall are extremely decorative.

\section{(6.) Cordyline australis ( $\mathrm{Ti}$, Cabbage-tree).}

A most ornamental tree of the lily family, having an erect trunk, finally branched above, each branch bearing a dense rounded head of long tapering sword-like thick leaves $2 \mathrm{ft}$. or more long. The sweet-scented cream-coloured tiny 
flowers are crowded together on great panicles 2-4 ft. long and $\mathrm{I}-2 \mathrm{ft}$. in diameter. It will grow in any kind of soil, wet or dry.

C. indivisa (the toii) is still handsomer, but far less easy to cultivate, and demands a much wetter climate. Its much broader leaves furnished with a reddish-yellow midrib and numerous lateral veins similarly coloured render it a conspicuous object. Both species of Cordyline are fairly hardy. They are effective when quite young.

\section{(7.) Corynocarpus laevigata (Karaka).}

A most attractive half-hardy tree with a stout trunk and dense rounded head of large shining dark-green leaves, somewhat resembling those of Magnolia grandiflora. The fruit is over I in. long, orange in colour, and extremely showy. The species can be grown near the sea.

\section{(8.) Dacrydium biforme (Yellow-pine).}

D. biforme is a round-headed or pyramidal tree, the branches below marked with old leaf-scars, but above bearing the small scale-like densely appressed leaves. Frequently the lower branches bear spreading juvenile linear leaves of quite a different type. D. Bidwillii is almost identical, but it is usually a low shrub. Both species are quite hardy, but grow best in a moist climate, cool in summer.

\section{(9.) Dodonaea viscosa (Akeake).}

A half-hardy coastal species with palish-green thin very narrow obovate leaves I-3 in. long. It can tolerate poor soil and excessive wind, but becomes much dwarfed in consequence. The fruits, with broad membranous wings, are of an unusual form.

\section{(10.) Dracophyllum longifolium (Inuka, Grass-tree).}

This hardy small tree is well worth cultivating on account of its striking contrast to most cultivated trees or shrubs. The upright close branches are for their greater part leafless, the long vertical needle-like leaves being confined to the extremities. It requires a rather moist situation, and thrives 
best in a cool climate. $D$. arboreum is very similar, but bears both the adult and much broader juvenile leaves at the same time.

\section{(11.) Entelea arborescens (Whau).}

An exceedingly handsome half-hardy small tree or shrub, 8-25 ft. high, somewhat resembling a mulberry. The leaves, on long stalks, have drooping cordate-ovate blades $4-9$ in. long, and the abundant snow-white flowers are $\mathrm{I}$ in. in diameter. The genus with its one species occurs only in New Zealand.

\section{(12.) Griselinia littoralis (Kapuka, Broad-leaf).}

An easily grown hardy tree or shrub of great beauty on account of its dense habit and bright-green glossy foliage of ovate leaves $\mathrm{I}-4 \mathrm{in}$. long. It bears clipping well, and is a desirable hedge-plant. G. lucida is still more striking with its. larger leaves, but it is not quite so hardy. It is only a shrub.

\section{(13.) Ixerba brexioides (Tawari).}

Almost the handsomest of the New Zealand evergreen trees. The flowers are white, $\mathrm{I} \frac{1}{2}$ in. in diameter, and arranged in terminal panicles. The leaves are thick, lanceolate; 3-6 in. long, and toothed. The tree is fairly hardy. The genus is confined to New Zealand, and contains only the one species.

\section{(14.) The Species of Leptospermum (Tea-tree).}

Two species, L. scoparium (the manuka) and $L$. ericoides (the kanuka), may eventually become trees, but in many places they are merely shrubs. Both possess heath-like foliage and white or, at times, pinkish flowers, which are produced in such profusion that the leaves may be almost hidden. There are many forms of both species, all of which are to be highly recommended.

The crimson form of L. scoparium, known as L. Nichollsii,* is one of the finest of garden shrubs. It is destined, in the hands of the plant-breeder, to yield an infinite variety of forms, since seedlings are excessively variable. There is also a double white manuka, not yet in general cultivation, but which is a most desirable novelty. 
(15.) Macropiper excelsum (Kawakawa).

A half-hardy tree or shrub with slender bamboo-like jointed branches and dark-green orbicular-cordate leaves 3-4 in. long.

\section{(16.) Melicope ternata (Wharangi).}

A charming much-branched half-hardy shrub or small tree, I0-20 ft. high, with bright-green 3 -foliate leaves, the leaflets oblong or obovate and $2-4$ in. long.

\section{(17.) Melicytus ramiflorus (Mahoe).}

A hardy, shrub or small tree belonging to the violet family, I0-30 ft. high. The leaves are dark-green, oblong-lanceolate, and 3-4 in. long. The inconspicuous flowers, succeeded by violet-blue berries, are borne on the naked twigs.

\section{(18.) Meryta Sinclairii (Puka).}

A noble araliad, 8-25 ft. high, with the immense shining oblong leaves, Io in. to more than $20 \mathrm{in.} \mathrm{long,} \mathrm{crowded} \mathrm{at} \mathrm{the}$ ends of the branches and borne on long leaf-stalks. The species is one of the rarest plants in the world, since it is found only on one or two small outlying islands of New Zealand. Unfortunately, it is not very hardy, but it makes a striking plant for a large pot or tub.

\section{(19.) Myoporum laetum (Ngaio).}

A low half-hardy tree with a head of straggling branches and soft dark-green broadly lanceolate leaves $\mathrm{I}-4$ in. long, but which are rendered paler by numerous oil-glands dotted over their surface. The small white flowers, spotted with purple, are rather pretty. The tree will grow vigorously close to the sea.

\section{(20.) The Species of Nothopanax.}

$N$. arboreum (the whauwhau-paku or ivy-tree) is a highly ornamental bushy tree, with striking shining dark-green 5-7-foliate leaves, the oblong leaflets $3-7$ in. long. The small purplish-black fruits, in large terminal compound umbels, are distinctly pleasing. The species is hardy, and of fairly rapid 
growth. $N$. Colensoi is similar to the above, but hardier. $N$. simplex has simple leaves when adult, but when juvenile they are 3-5-foliate and the leaflets deeply cut. N. Edgerleyi is similar to the last-named; both are hardy, but they demand more shade and moisture than the other species cited above.

\section{(21.) The Species of Olearia.}

These are the tree-asters; some are both trees and shrubs, others shrubs alone. The genus in New Zealand contains at least forty species. Many are subalpine or alpine plants, whose hardiness is undoubted. All are well worthy of cultivation. The leaves are usually leathery and covered with a dense mat of hairs on the under-surface. In most of the species the flower-heads are small, deliciously scented, and the florets white, much after the manner of Aster ericoides, and they are produced in such profusion as to be extremely showy. $O$. semidentata, a shrub, has florets of the most brilliant purple imaginable, and is a truly magnificent species; unfortunately, it is difficult to cultivate under ordinary garden conditions. The most important of the tree-olearias for horticulture are the following :-

$O$. Traversii, an excellent shelter-plant and invaluable for sand-dune reclamation; $O$. furfuracea; $O$. arborescens (syn. O. nitida); O. macrodonta; $O$. ilicifolia, the New Zealand holly; O. Cunninghamii, a forest-plant, only half-hardy; $O$. excorticata; $O$. suavis; $O$. lacunosa, a remarkable species with stiff narrow-linear leaves 4-7 in. long, which beneath, through the raised midrib and numerous lateral veins, have the surface divided into sunken interspaces; $O$. avicenniaefolia; $O$. albida, half-hardy; O. Forsteri; O. tragrantissima* and O. Hectori.*

Some of the above make most excellent hedges especially O. Forsteri, O. ilicifolia, O. mxcrodonta, and $O$. Traversii.

\section{(22.) Pennantia corymbosa (Kaikomako).}

A handsome flowering-tree, some 20-30 ft. high, with oblong or obovate leaves $I-4$ in. long, and abundant fragrant small

* These are deciduous, but it is convenient to mention them here. 
white flowers. The juvenile form is quite different in leaf and habit, and the same tree may be adult above and juvenile below, so that it looks as if consisting of two different species.

(23.) Persoonia toru (Toro).

A handsome fairly hardy small tree, I5-30 ft. high, of symmetrical form, with reddish-brown twigs and thick shining long very narrow leaves 4-8 in. in length, which are rather pale-green above, but purple or dotted with that colour beneath.

\section{(24.) The Species of Pittosporum.}

Pittosporum is an important genus in New Zealand, containing about nineteen species-some trees, others shrubs. The most important of the trees are,-

$P$. tenuifolium (syn. $P$. nigrescens); $P$. Colensoi; $P$. fasciculatum; $P$. Buchanani (this and all the above species are very closely related, and contain many distinct.forms difficult to classify); $P$. Huttonianum; $P$. patulum; $P$. Dallii (not yet in cultivation, but a splendid hardy tree with white sweetscented flowers); $P$. ellipticum; $P$. Ralphii; $P$. crassifolium; $P$. Fairchildii; $P$. umbellatum; and $P$. eugenioides.

Several of the above are excellent for hedges, especially $P$. tenuifolium, $P$. Colensoi, and $P$. Ralphii. $P$. crassifolium can be grown close to the sea. $P$. eugenioides is most handsome with its shining elliptical leaves $2-4$ in. long, their margins wavy, and its compound umbels of small yellow flowers.

$P$. obcordatum must now be almost the rarest wild plant in the world, since but one or two trees are all that are known to exist. It is not yet in cultivation.

(25.) Pomaderris apetala (Tainui).

A fairly hardy shrub or small tree, $20 \mathrm{ft}$. high, with wrinkled oblong-ovate leaves 2-4 in. long, greyish beneath. The species is of easy cultivation and fairly rapid growth.

\section{(26.) The Species of Pseudopanax.}

The genus is confined to New Zealand, and contains seven species. $P$. crassifolium (hardy) and $P$. ferox (hardy) are especially remarkable, in that the juvenile and adult forms are 
altogether distinct, the former persisting for many years. This juvenile state consists of an unbranched main stem, from which pass off, at intervals, excessively thick, long, narrow, toothed leaves, 6-36 in. long (in the case of $P$. crassifolium), and $\frac{1}{4}-\frac{1}{2}$ in. wide. The juvenile leaf or $P$. ferox possesses large sharp, almost spinous, teeth. These juvenile plants have a special character of their own for garden decoration. The adult leaves only appear when the tree is some $10 \mathrm{ft}$. or more tall and it has branched. The final leaves, 4-8 in. long, are linear or linear-obovate.

$P$. chathamicum is similar to the above, but it does not pass through a deflexed narrow-leaved juvenile stage.

Other species worth cultivating are $P$. Lessonii (half-hardy) and $P$. discolor (half-hardy), this latter - with bronzy leaves, but hardly a tree.

\section{(27.) The Species of Quintinia.}

There are two closely related species-Q. serrata (halfhardy) and $Q$. acutifolia (hardy). Both have yellowish-brown leaves and short racemes of pale-lilac flowers. They require a moist shady situation. In addition to the above, the genus contains only two other species, both Australian.

\section{(28.) Rapanea Urvillei (Mapau).}

A hardy shrub or tree, I0-20 ft. high, with red twigs, oblong leaves $\mathbf{I}-2$ in. long, with crinkled margins, and numerous small black fruits $\frac{1}{8}$ in. in diameter. It closely resembles Pittosporum tenuitolium.

\section{(29.) Rhopalostylis sapida (Nikau).}

A handsome half-hardy palm, $20 \mathrm{ft}$. or more high, but of slow growth. The great pinnate leaves are $4-8 \mathrm{ft}$. long. $R$. Bauevi is very similar, but attains greater dimensions.

\section{(30.) The Species of Senecio (Groundsel).}

The groundsels, usually humble herbs elsewhere, in New Zealand attain to the dignity of shrubs or even trees.

$S$. Huntii (the rautini) is a magnificent object when lit up by its masses of brilliant golden flower-heads. The tree itself 
is finally more than $20 \mathrm{ft}$. high, and even when not in flower its general habit and foliage, bluish-green in the mass, render it remarkably attractive. The rarer $S$. stewartiae is closely related.

S. rotundifolius (the mutton-bird scrub) is equally remarkable through its thick shining leathery orbicular leaves, 3-5 in. in diameter, covered beneath with a close mat of pale buffcoloured hairs. It is a splendid hedge-plant for exposed seashore positions, where the climate is moist.

S. elaeagnifolius, a near relative, is particularly hardy.

All the above require a fairly moist soil; they grow readily from cuttings.

\section{(31.) Suttonia chathamica (Matipo).}

A hardy shrub or small tree, some $20 \mathrm{ft}$. high, with dark bark and glandular dotted obovate leaves $I-2$ in. long. The small mauve-coloured fruits, $\frac{1}{4}$ in. long, are distinctly pleasing. It will thrive near the sea.

\section{(32.) Veronica gigantea.}

A tree $40 \mathrm{ft}$. high under favourable conditions, with a stout trunk. It much resembles the shrubby $V$. salicifolia in its willow-like foliage and also its flowers, but in its young form is quite distinct owing to. the purple hairy stem and leaves with abundant hairs on their margins. It is not very hardy. Can be readily grown from cuttings or seed.

\section{SMALL MORE OR LESS DECIDUOUS TREES.}

\section{(1.) Aristotelia racemosa (Makomako, Wineberry).}

A hardy shrub or tree of rapid growth, I0-30 ft. high, with bright-green thin toothed ovate leaves $2-5$ in. long, and rather pleasing sweet-scented rose-coloured flowers, in panicles which are succeeded by red or black berries.

\section{(2.) Fuchsia excorticata (Kotukutuku, New Zealand Fuchsia).}

A shrub, or eventually a tree, $40 \mathrm{ft}$. high, with a thick irregular trunk, from which hang long ribbons of brown 
papery bark. The leaves, green above and silvery beneath, are thin, lanceolate, and about 3-4 in. long. The flowers, which appear while the tree is leafless or nearly so, are $I$ in. or more long, pendulous, green and purple at first but fade to a dull red. There is a desirable form with purplish leaves. The species is fairly hardy. Grows from cuttings.

\section{(3.) The Species of Gaya (Mountain Ribbonwood).}

There are two closely related species, G. Lyallii and G. ribifolia. Both are most charming small trees when covered thickly with their white cherry-like blossoms, I in. in diameter. The leaves are ovate and $2-4$ in. long; those of $G$. Lyallii a tender green, and those of G. ribifolia somewhat grey owing to their numerous hairs. They may be grown from cuttings; both are hardy, but $G$. ribifolia is more tolerant of drought. Before falling, the leaves assume a pleasing autumnal colouration.

\section{(4.) The Species of Hoheria (Houhere, Lacebark).}

There are at least three species of Hoheria, a genus confined to New Zealand-H. populnea, $H$. sexstylosa, and $H$. angustifolia - the first-named being evergreen and not so hardy as the other two. All are most desirable on account of their beautiful and abundant white flowers and graceful habit. $H$. sexstylosa is of extremely rapid growth, while plants six years old may blossom. The juvenile forms of $H$. angustifolia and $H$. sexstylosa are distinct from the adult, and may persist for many years. The species flower at different times of the year. All may be raised from seed.

\section{(5.) Plagianthus betulinus (Manatu, Lowland Ribbonwood).}

The greenish flowers, though in large clusters, are inconspicuous, but the dense habit and tender green of the ovate toothed leaves, I-3 in. long, render this hardy quick-growing tree worthy of a place in any fair-sized garden. The juvenile stage is much like that of. Hoheria and Pennantia. 
(6.) The Species of Sophora (Kowhai).

There are four species, S. grandiflora, S. tetraptera, S. microphylla, and $S$. prostrata, the last being a shrub and also a permanent juvenile form of $S$. microphylla. All the species are exceedingly handsome when covered with their gorgeous golden-yellow flowers each $\mathrm{I}-2$ in. in length. Also, the narrow pinnate leaves, several incheslong, add to the charm of the tree. All are fairly hardy. S. grandiflora is the most showy, and blooms at an earlier age than do the other species.

\section{EVERGREEN SHRUBS.}

\section{(1.) Alseuosmia macrophylla (Hoihoi).}

A half-hardy shrub of irregular habit, 4-8 ft. high, with slender branches, glossy dark-green leaves (variable in shape, but often ovate-lanceolate) 3-6 in. long. The flowers are deliciously scented, yellow or crimson, and $\mathrm{I}-\mathrm{I} \frac{1}{2}$ in. long. Requires cultivating in a moist shady situation.

\section{(2.) The Species of Cassinia.}

C. Vauvilliersii, C. albida, and C. fulvida are quite hardy, C. leptophylla, $C$. retorta, and $C$. amoena are more tender. All are somewhat heath-like in appearance. They are of pleasing aspect, and showy when in bloom with their white flower-heads. C. amoena is $\mathrm{I}-2 \mathrm{ft}$. high, but the others may reach $6 \mathrm{ft}$. The small leaves are covered beneath with a thick mat of hairs which are generally white, except in the case of $C$. fulvida, where they are dull yellow. All the species are easy to cultivate, and will grow in almost any soil and situation, except shade.

\section{(3.) Clianthus puniceus (Kowhai-ngutukaka, Red Kowhai, Par- rot-bill).}

Exceedingly handsome with its abundant brilliant scarlet pea-like flowers $2-3 \mathrm{in}$. long, and linear-oblong pinnate leaves 4-6 in. long. It attains a height of $6 \mathrm{ft}$. or more. The stems, in part, are herbaceous rather than woody. There is a desirable white-flowered variety which comes "true" from seed. Both are fairly hardy.

Inset-N.Z. Plants, \&c, 


\section{(4.) The Species of Coprosma.}

The greater part of the hardy species are not worthy of garden culture, except in large collections. Many, however, when in fruit are handsome, through the abundance of their translucent drupes of rather brilliant colours. In this regard the hardy prostrate C. brunnea, with lovely blue* drupes, is of value in any rock-garden. C. ramulosa, with red drupes, is also to be recommended. ' C. serrulata, 2-3 ft. high, a subalpine species, is distinctly striking with its far-creeping habit, thick pale-green roundish leaves I-2 in. long, and reddish drupes. In order that the species of Coprosma shall fruit, both male and female plants must be grown in close proximity.

Several of the less hardy species are handsome shrubs, especially $C$. grandiflora, with more or less oblong leaves 4-9 in. long, the somewhat similar C. lucida, and C. tenuifolia.

\section{(5.) Cordyline Banksii (Ti-ngahere).}

A very handsome, fairly hardy plant resembling $C$. indivisa, but not eventually so tall, and much easier to cultivate. The forms with red midribs should be procured. It will grow in almost any kind of soil.

C. pumilio is usually stemless; its leaves are narrow and grass-like. It makes a good pot-plant.

\section{(6.) Coriaria ruscifolia (Tutu).}

Several forms, distinct for garden purposes, are included under the above name. They vary from herbaceous plants, the subterranean parts of which alone are perennial, to shrubs or even small trees, attaining at times a height of more than $25 \mathrm{ft}$. The leaves are thin, ovate, I-3 in. long, and the plant bears abundant many-flowered drooping racemes, which finally carry large quantities of small handsome purplish-black fruits. All the parts of the plant are highly poisonous.

\section{(7.) The Species of Corokia (Korokia).}

C. buddleoides and C. chathamica are almost identical species; the latter at times may be considered a tree.

* There is every shade, from amethyst to the palest shade of bluc. 
Their shining lanceolate dark-green leaves, silvery beneath, are 2-6 in. long. They bear abundant small yellow star-like flowers, which are succeeded by dark-red drupes. Both species are moderately hardy.

C. Cotoneaster is a hardy shrub, 3-6ft. high, with rigid much-interlaced wiry branches and orbicular or oblong leaves, white beneath. When covered with the starry yellow flowers, or the orange, yellow, or red drupes, looking like tiny apples, the effect is very pleasing. $C$. Cheesemanii is intermediate between $C$. Cotoneaster and $C$. buddleoides. All the species grow readily even in dry soil.

\section{(8.) Dacrydium laxifolium.}

This 1emarkable conifer varies in height from about $I$ in. to $\mathrm{Ift}$. or $2 \mathrm{ft}$. 'It has slender trailing branches, which bear either the juvenile spreading short narrow leaves, or the adult imbricating scale-like ones. The fruit is a small nut seated on a red fieshy receptacle. Being a high-mountain plant, it is quite hardy. Its most common station is wet peaty ground.

\section{(9.) The Species of Dracophyllum.}

These are frequently erect slender-stemmed shrubs with long needle-like rather grassy leaves, as already described for D. longifolium. Several are worth cultivation on account of their peculiar form, but usually they are not easy to grow. The following are suitable for gardens: D. Urvilleanum and its allies, D. Sinclairii (a species with rather broad leaves), D. uniflorum, D. acicularifolium, D. paludosum, and D. subulatum. Hardly any of the species are yet in cultivation. Most would be hardy.

\section{(10.) The Species of Drimys.}

D. axillaris (horopito) is a half-hardy shrub or, at times, a tree, with black stems and glossy elliptic-ovate leaves 2-5 in. long. The closely allied D. colorata, with yellowishgreen leaves blotched with red, and glaucous beneath, is a hardier and perhaps more striking shrub, which, moreover, can bear a good deal of exposure. D. axillaris demands a moist, shady position. The leaves of both species being hot when chewed, have led to the name of "pepper-tree." 


\section{(11.) The Species of Gaultheria.}

This genus, which also occurs in North America, is represented in New Zealand by several beautiful hardy species. The most striking is G. oppositifolia, a shrub of straggling habit, 2-6ft. high, with stem-clasping thick ovate leaves $I \frac{1}{2}-2 \frac{1}{2}$ in. long, and terminal panicles 2-4 in. long, bearing numerous beautiful white flowers resembling those of the lily-of-thevalley.

G. rupestris is almost equally beautiful, and some forms attain a height of Io ft.

G. depressa is a charming hardy creeping-shrub for the rock-garden, with its large white berries.

Under the name of $G$. antipoda there are a number of distinct plants, mostly quite low shrubs, any of which are desirable hardy plants.

\section{(12.) Helichrysum microphyllum.}

A remarkable plant of the aster family, it being of the cypress form, with scale-like leaves pressed close to the stems. It bears abundance of small yellow flower-heads. The allied $H$. coralloides, a truly marvellous species, has much thicker stems, with the leaves looking like glossy tubercles, while the spaces between are filled with white woolly hairs. $H$. Selago is intermediate between the above species. All are quite hardy, but the two latter are not easy to cultivate. In any case the rock-garden is the place for these curious shrubs.

\section{(13.) The Species of Myrtus.}

The most important is the fairly hardy $M$. bullata, a handsome and uncommon-looking shrub, or even low tree, with roundish reddish-brown leaves $\mathrm{I}-2$ in. long, the surface of which is raised into blisters. The white flowers, $\frac{1}{2}$ in. in diameter, are rather pretty. $M$. Ralphii is very similar, but the leaves are much flatter. $M$. obcordata, also at times a low tree, has very small obcordate leaves. $M$. pedunculata is somewhat similar but smaller. The two last species may be considered hardy. All the species are easy to cultivate. 


\section{(14.) The Species of Olearia.}

Those already described as low trees will generally remain as shrubs in gardens, especially in a dry climate. Other species of similar habit, but purely shrubby, are $O$, moschata, with small obovate-oblong leaves more or less white on both surfaces; O. Haastii, somewhat similar, but with larger leaves, $O$. oleifolia, like a small-leaved form of $O$. avicenniaefolia; O. nummularifolia, with extremely thick, small roundish leaves; and $O$. cymbifolia, similar to the last-named, but the margins of the leaf so much recurved as to make it boat-shaped. All the above are quite hardy, easily grown, and strike readily from cuttings.

O. insignis differs so much from the other species that it should form the type of a new genus. It is a low-growing shrub with long spreading branches, which at their extremities bear, in rosettes, the beautiful leathery oblong leaves, each I-4 in. long, glossy-green above, but beneath thickly covered with a close mat of white hairs. The young branches, too, are similarly clad. The flower-head, raised on white stalks 4-8 in. long, is hemispherical, 2-3 in. in diameter, and surrounded by many involucral scales which are white from their mat of hairs. The outer florets are white and the inner yellow. Since the species is confined in its natural habitats to dry rocks it will grow in exceedingly arid soil. It is quite hardy. No New Zealand plant more deserves cultivation.

There are several remarkable species with stiff lanceolate toothed leaves, covered beneath with a soft mat of white hairs, the ultimate branches being similarly adorned. They have all large, usually solitary, flower-heads, which in some of the species have the florets altogether or in part purple. The delightful $O$. semidentata has been already referred to. Other species are $O$. chathamica, $O$. operina, $O$. angustifolia, ${ }^{*}$ and $O$. Traillii. $O$. Colensoi and $O$. Lyallii may be here included, but their leaves are much broader, those of $O$. Lyallii being extremely large, and their flower-heads far less showy. $O$. Lyallii is a tree rather than a shrub.

These large-headed olearias require a moist, equable climate with low summer temperature, and are not suited to ordinary garden conditions.

* Eventually a low, round-headed tree. 


\section{(15.) The Species of Pimelea.}

These are desirable garden-shrubs varying in stature from $6 \mathrm{ft}$. ( $P$. longifolia) to plants of prostrate habit $(P$. Lyallii, $P$. prostrata). They produce abundance of small white flowers in compact, usually many-flowered heads. In many species the stems, or these and the leaves, are covered with silky hairs.

$P$. longifolia is a handsome erect shrub, with slender branches, and lanceolate leaves $\mathrm{I}-3$ in. long. The flowers are rather like those of the jasmine. $P$. Gnidia and $P$. buxifolia are similar, but less easy to cultivate. Amongst the smaller species that can be recommended are $P$. Lyallii, $P$. Traversii, and $P$. prostrata, all of which are hardy.

\section{(16.) Podocarpus nivalis (Mountain-totara).}

A much-branched far-spreading shrub, which in cultivation might reach a height of 4-6 ft. In leaf, \&c., it closely resembles $P$. totara, already dealt with. $P$. acutifolius is somewhat taller, and with sharp-pointed leaves. Both are hardy. Their brown colour gives a special character to the plants.

\section{(17.) The Species of Senecio.}

All the shrubby species of Senecio are highly desirable plants, especially the hardy subalpine members of the genus. In most cases the leaves are leathery, and covered beneath with a close mat of hairs, which may resemble white kid glove. The yellow flower-heads, produced in profusion, render these shrubs extremely showy. S. laxifolius, S. compactus, $S$. Monroi, $S$ cassinioides (leaves very small, plant strongly aromatic), and $S$. Bidwillii are all hardy and easy to cultivate.

S. Kirkii is a most beautiful half-hardy shrub, with smooth leaves $2-5$ in. long, but extremely variable in form. The numerous pure-white flower-heads, each 2 in. in diameter, render the plant extremely conspicuous.

$S$. perdicioides is another very fine species, which is fairly hardy. The thin oblong leaves, about $I_{2}$ in. long, are quite without hairs. 


\section{(18.) The Species of Veronica.}

The species of Veronica are perhaps the most important of all New Zealand plants for garden purposes. The genus contains at least one hundred more or less distinct species, and some of these, again, many forms which would be amply distinct in any gardener's estimation. Here it is impossible to attempt more than the briefest description of the genus from the horticultural standpoint.

Not only does Vercnica, in New Zealand, yield a great variety of species, but also there are astonishing differences in their forms. Thus the shrubs may be prostrate or erect, compact and ball-like or straggling, densely leafy or the leaves reduced to scales and the plant resembling a cypress (the whipcord veronicas). Then, there are all degrees in height, from tall shrubs $I_{5} \mathrm{ft}$. or more to those not raised more than I in. above the ground. The flowers, too, differ considerably ; they may be in small heads, racemes of various length, or long branched panicles. The colour is usually white, but crimson, lilac, violet, and blue are met with. In many species the leaves are green, but in some they are glaucous.

Nearly all are easy to cultivate-seeds germinate rapidly, cuttings strike readily, many are not fastidious as to their water-requirements. The greater number of the species are as hardy as any New Zealand plants, especially those with glaucous foliage. If cuttings are taken from adult plants in the autumn, they will bloom during the succeeding summer. Such small plants can be bedded out in the rock-garden, \&c., where they are most effective. The compact-growing veronicas lend an admirable effect to the garden landscape when massed together upon banks, but without touching, those of the balllike form being specially suited for this purpose, and looking as if they had been purposely trimmed into their shape; indeed, nearly all the leafy erect species bear clipping to any extent. Several species '(V. elliptica, $V$. parviflora, $V$. Traversii, $V$. leiophylla) make excellent hedges. A small form of $V$. buxifolia can be used satisfactorily as an edging to a flower border, after the manner of the box.

The following selection of distinct species may serve as a guide to the gardener, but it must be pointed out that many 
errors have crept into the horticultural nomenclature of this genus, and it is difficult to obtain plants "true to name": $V$. speciosa (half-hardy,* crimson); $V$. Dieffenbachii (wide spreading, leaves pale-green); $V$. salicifolia; $V$. macrocarpa var. latisepala (deep violet); V. Lewisii (blooms in autumn, lilac) ; $V$. chathamica (prostrate, lilac, there are many forms); $V$. angustifolia (leaves rather long and narrow); $V$. diosmaefolia (lilac, early blooming); $V$. elliptica (hardly hardy, blue fading quickly to white); V. Mattheresii (spreading habit, leaves rather broad but short, lilac); $V$. Traversii (ball-like, white); $V$. subalpina (leaves glistening-green, early blooming); $V$. glaucophylla (ball-like, glaucous leaves); V. vernicosa (lowgrowing, glossy leaves, very floriferous); $V$. buxifolia var. odora (ball-like, leaves varnished); $V$. decumbens (prostrate, leaves with red margin); $V$. amplexicaulis low-growing, farstraggling, leaves short but broad, glaucous); $V$. pinguifolia (usually prostrate, leaves glaucous); V. glauco-caerulea (blue, leaves small, glaucous); $V$. Hectori, $V$. lycopodioides, $V$. cupressoides, V. Armstrongii, V. salicornioides, V. propinqua (various distinct species of the whipcord form); $V$. epacridea (leaves recurved, margins red, prostrate, straggling); $V$. macrantha (flowers $\frac{3}{4}$ in. diam.); V. Benthami (brilliant blue); V. Hulkeana (blooms early, the beautiful soft lilac flowers in corymbs Ift. long); $V$. Lavaudiana (pale-rose in bud, leaves margined red); $V$. Raoulii (lilac, blooms early). Many species, equal to most of the above, are omitted; in fact, it is not easy to make a selection.

\section{MORE OR LESS DECIDUOUS OR LEAFLESS SHRUBS.}

\section{(1.) The Species of Carmichaelia.}

This curious genus, belonging to the pea family, has the leaves generally reduced to small scales, while the terete or flattened stems are green. The small flowers are usually more or less purple and sweet-scented. They vary from plants forming small close patches, which may be circular in outline, to shrubs more than I2 ft. high. Generally speaking,

* Unless otherwise stated the species are hardy. 
the majority are more curious than ornamental; still, the small species (C. nana, C. uniflora, C. Monroi) are suitable for the rock-garden. The following may, however, be recommended : C. Williamsii (stems $\frac{1}{3}$ in. broad, flowers I in. long, yellowish-red) ; C. grandiflora (leafy in summer, flowers strongly scented); C. odorata (ro ft. high, leafy in summer, extremely floriferous).

\section{(2.) Fuchsia Colensoi.}

Has much more slender stems than $F$. excorticata, and, if required, can be made to cover trellis-work, \&c. It is fairly hardy. F. procumbens may also be mentioned, a plant with slender trailing stems and abundant large red berries, which, as a pot-plant, is highly decorative.

\section{(3.) Notospartium Carmichaeliae (Pink Broom).}

A hardy shrub after the manner of Carmichaelia, some Io ft. high. The flowers, $\frac{1}{4}-\frac{1}{3}$ in. long, are pink and produced in great profusion. A most desirable and beautiful plant, which will grow in very dry soil.

\section{(4.) Olearia lineata (syn. 0. virgata var. lineata).}

A much-branched shrub with dense slender twigs, and very narrow leaves $I$ in. or more long, covered beneath with a greyish mat of hairs. The flower-heads, though small, are numerous and sweet-scented.

\section{(5.) Senecio Hectori.}

A tall shrub with much the form of a rhododendron. The large leaves are broadly lanceolate, 6-I2 in. long, and covered beneath with a mat of white hairs. The large flower-heads are white, and arranged in great corymbs a foot or more across. The species is fairly hardy, but demands a moist shady position:

\section{CLIMBING-PLANTS.}

New Zealand contains a wealth of woody climbing-plants, some of which form great "ropes" in the forest, after the manner of tropical lianas. Several succeed admirably in cultivaticn, and are of considerable beauty. 


\section{(1, The Species of Clematis.}

The male and femala flowers are on separate plant:; only the male are worth cultivating, unless seed is wanted. $C$. indivisa is by far the handsomest species, with its great garlands of pure-white blossoms 3-4 in. in diameter. C. Colensoi, with cream-coloured flowers, is also worth cultivation. The remarkable C. afoliata, a species without leaves, is not merely a curious but a striking plant, either when growing in shrubfashion with its green rush-like greenish-yellow stems forming a dense mass on the ground or when climbing. Its flowers are pale yellow. All the above are hardy. Seed of Clematis germinates slowly.

\section{(2.) The Species of Metrosideros.}

Climbing species of the myrtle family are confined to New Zealand. $M$. florida is a half-hardy root-climber with brightgreen glossy leaves and brilliant yellowish-red flowers produced in the late autumn. $M$. diffusa (half-hardy) is especially lovely with its rosy-crimson flowers. Other species worth cultivating are $M$. albiflora (half-hardy), and $M$. hypericitolia (hardy). All require a fair amount of shade.

\section{(3.) The Species of Muehlenbeckia.}

$M$. australis, with soft ovate bright-green leaves $2-3$ in. long, is a rapidly growing winding-plant that quickly drapes a tree or other support with a dense green mantle. $M$. complexa, of similar habit, is rather more hardy, but its leaves are smaller.

\section{(4.) The Species of Parsonsia.}

There are two fairly hardy, closely related species, the one with small, white, jasmine-like flowers $(P$. heterophylla) and the other in which they are sometimes more or less rose-coloured (P. capsularis).

\section{(5.) The Species of Rubus.}

The most important is $R$. australis, which climbs by means of hooked prickles on the midribs of the leaf. Its huge bunches 
of pure-white flowers make the plant extremely showy in the spring.

M. cissoides var. pauperatus has the leaves almost or quite reduced to midribs. It forms rounded entangled masses in the open, which are brightened by their numerous yellow prickles. Both species are hardy.

The trailing but non-climbing species, $R$. parvus and $R$. Barkeri, may be mentioned here. Both have most beautiful foliage, especially in autumn and winter, when it is of a bronzish hue. $R$. parvus produces abundance of large scarlet fruits, but $R$. Barkeri has never been known to flower.

\section{(6.) Tetrapathaea australis.}

Closely related to the passion-flowers. The genus is confined to New Zealand, with only the one species. It is a tendril climber of rapid growth, distinguished by its beautiful glossy foliage and later its pretty orange fruits.

\section{(7.) Senecio sciadophilus.}

A climbing groundsel with thin round leaves $\mathrm{I}-2$ in. long, and numerous small yellow flower-heads. It is fairly hardy.

\section{HERBACEOUS AND SEMI-WOODY PLANTS.}

Unlike so many herbs of the temperate Northern Hemisphere, those of New Zealand do not, except in comparatively few cases, die to the ground yearly. Therefore, these perennial laaves are often stiff and leathery, or covered beneath with a dense mat of hairs resembling flannel, felt, leather, \&c. Further, the plants under consideration occur chiefly in the high mountains, where, in early and mid. summer, there are most beautiful natural flower-gardens. Strange to say, however, there are few red, blue, or purple flowers, nearly all being either white or yellow. Many of these mountain-plants are not easy to cultivate in the lowlands, unless in specially prepared rock-gardens where shade, perfect drainage, and abundance of moisture are supplied. Where there is a sufficiently moist climate and a low summer temperature many 
species can be grown in the ordinary open border. Almost all can be cultivated successfully as pot-plants in a cold frame. In a dry climate, if the roots are wrapped in wet Sphagnum moss before planting, there is a greater chance of success than if planted unmossed. Many of the species are worthy of a little trouble, since they are amongst the finest alpine plants in the world. Here comparatively few species are dealt with, and generally those most amenable to cultivation.

\section{(1.) Acaena microphylla.}

A rather pretty hardy plant for forming glaucous-coloured mats on rockwork. The spines of the ripe heads of fruits are bright red, rendering the plant conspicuous. There are several distinct varieties, in some of which the leaves are of a pleasing brownish hue.

\section{(2.) The Species of Aciphylla.}

The genus belongs to the carrot family, and is remarkable for the Yucca-like form possessed by some of the species, which renders them ornamental objects in any mixed border. The most important for gardens are $A$. squarrosa, A. Colensoi, $A$. maxima, and $A$. conspicua. All have great rigid spinous pinnate leaves, and tall flower-stalks which in $A$. maxima attain a height of 6-Io ft. A. Monroi is a charming little rockplant, a few inches tall, looking like a palm in miniature.

\section{(3.) The Species of Anisotome.}

The most important is A. latifolia, a magnificent plant with thick leathery dark-green fern-like leaves $2 \mathrm{ft}$. or more long, and a stout flower-stalk $3 \mathrm{ft}$. or more high, bearing a massive head of rosy-purple or rosy-lilac flowers.

$A$. antipoda is very similar, but the leaves are more finely cut and the flowers of a brighter colour. Both species demand moisture and shade. They are quite hardy.

\section{(4.) Arthropodium cirrhatum (Rengarenga, Mabel Island Lily).}

A rather showy herb with moderately broad smooth leaves I-2ft. long, above which is raised the flowering-stem, its 
termination for $\mathrm{I} f$. or so bearing numerous pleasing white flowers, each about I in. in diameter. It is fairly hardy, and will grow in quite dry ground.

\section{(5.) Arundo conspicua (Toetoe).}

A huge tussock-grass after the manner of the pampasgrass, but with more graceful plumes. It is hardy; and although it grows best in fairly wet but well-drained ground, it will thrive in quite dry soil.

\section{(6.) The -Species of Astelia.}

These plants of the lily family are of the tussock-form, with long sword-like leaves. The extremely hardy $A$. montana has a rather silvery leaf with a coloured midrib. A. nervosa, A. Cunninghamii, A. trinervia, and A. Solandri are more massive species, but not quite so hardy. All make ornamental plant; for pot culture.

\section{(7.) The Species of Celmisia.}

This is the most important genus in New Zealand, so far as the herbs and semi-woody plants are concerned. It contains at least fifty species. The genus is related to Aster. The flower-heads, raised on stiff stems, have abundant white ray-florets, and in some species are more than $5 \mathrm{in}$. across. The leaves, in depressed or erect rosettes, are often of a beautiful silvery colour. Some species form silvery mats, others dense silvery cushions. Generally speaking, all require rock-garden conditions. The following would be a good selection: C. holosericea: C. coriacea (silvery lanceolate leaves, heads of the largest size); $C$. Traversii (leaves with an edging of rust-coloured hairs, which contrast agreeably with the green upper surface); $C$. rigida (similar to the last, but far more easy to cultivate); $C$. Armstrongii and $C$. lanceolata (leaves with a yellow or orange midrib); C. Hookeri, syn. C. verbascifolia of gardens (one of the easiest to grow, flower-heads of great size); C. Lindsayi, C. discolor, C. Walkeri, C. incana (form circular mats, the last-named covered more or less with a white woolly mat of hairs); $C$. sessiliflora and $C$. argentea (forming silvery cushions). Fine hybrids have been made by crossing C. Hookeri, C. coriacea, and C. Traversii. 


\section{(8.) The Species of Cotula.}

These are mat-forming plants with usually short somewhat fern-like leaves, excellent for covering stones, \&c., in the rockgarden. They bear multitudes of small pale-coloured rayless flower-heads on very slender stalks. Useful species are Cotula Muelleri (green leaves); C. Traillii (brown leaves); C. Haastii; and $C$. squalida. C. plumosa, with beautiful pale-green feather-like leaves $4-6$ in. long, is extremely graceful, but rather difficult to cultivate.

\section{(9.) Danthonia Cunninghamii.}

An exceedingly handsome tussock-grass with flat leaves 3-4 ft. long, and large open graceful panicles 4-5 ft. high. It is quite hardy, and not fastidious as to soil or station.

\section{(10.) The Species of Epilobium.}

Some of the small-flowered mat-forming species might be used with pleasing effect in the rock-garden as annuals where the winter climate is severe enough to kill all the seedlings, otherwise they are apt to become a nuisance. E. nummularifolium, E. pedunculare, and E. nerterioides are suitable.

\section{(11.) Geranium Traversii var. elegans.}

A rather pretty plant with silvery leaves, and pink flowers $\mathrm{I}$ in. in diameter. It is fairly hardy.

\section{(12.) Helichrysum bellidioides.}

A hardy creeping-plant forming mats of silvery leaves, and producing numerous "everlasting" white flower-heads. It will grow in dry ground.

\section{(13.) Linum monogynum.}

A fairly hardy flax, $\mathrm{I} \frac{1}{2}-2 \mathrm{ft}$. high, with delicate large white flowers. Can be grown near the sea.

\section{(14.) Myosotidium nobile.}

A splendid giant forget-me-not. The glossy leaves on stout stalks, $\frac{1}{2}-\mathrm{Itt}$. long, have broad ovate-cordate blades 
about Ift. in length. The flower-stalk, perhaps $2 \mathrm{ft}$. high, bears at its extremity a mass of the beautiful flowers, each $\frac{1}{2}$ in. or more in diameter. In colour the central part of the flower is bright blue, and the marginal part paler or even white. There is also a white variety which comes "true" from seed. Myosotidium should be raised from seed and grown in a moist, not too sunny, situation. It is fairly hardy, and might be naturalized on sandy ground near the sea. It is not suitable for pot culture.

\section{(15.) The Species of Myosotis.}

There are a good many species of forget-me-not in New Zealand, whose colour is rarely blue, but yellow, bronze, brownish, or white. Most are not easy to cultivate, nor is seed readily procurable. The blue $M$. capitata of the Lord Auckland Islands is one of the most beautiful plants in the New Zealand flora.

\section{(16.) The Species of Nertera.}

$N$. depressa forms mats of tiny leaves upon the ground, which, when almost hidden by the abundant shining red fruits, are extremely pleasing. The recently discovered $N$. Balfouriana, with orange-coloured fruits, is equally showy. Both species are hardy. They prefer moist ground, but may also be used as pot-plants.

\section{(17.) The Species of Ourisia.}

These are charming hardy herbs with white flowers, all being worthy of a foremost place in any rock-garden. They require moist soil, good drainage, and a fair amount of shade. $O$. macrophylla is perhaps the handsomest, with its green smooth ovate leaves, 4-6 in. long, borne. on stout stalks 3-4 in. long, and the rather large flowers arranged in whorls one above another upon stout flower-stems $\mathrm{Ift}$. or so tall. $O$. macrocarpa and $O$. caespitosa are other desirable species.

\section{(18.) The Species of Phormium (New Zealand Flax).}

There are two species, $P$. tenax and $P$. Cookianum, and many varieties of both, some of which are variegater. All 
the forms are magnificent decorative plants, both for the open border and for indoor use. They will grow in any. kind of soil and position. In appearance, Phormium resembles a gigantic Iris, the thick sword-like leaves are at times $9 \mathrm{ft}$. long or more; they are tightly bunched together below, but above they open out somewhat, and frequently droop near their extremities. The flowers, of a lurid red in $P$. tenax and yellowish-red or greenish-red in $P$. Cookianum, are borne on stout stalks 6-I5 ft. high. Propagation is from seeds or by pieces of the rootstock. The dark purplish-brown form of $P$. tenax is much brighter-coloured when young, and at that stage is very effective. Apart from its ornamental value, $P$. tenax is a highly important economic fibre-plant.

\section{(19.) The Species of Ranunculus.}

Unfortunately, the large-flowered New Zealand species of buttercup are not easy to cultivate, except in certain favoured localities, where the climate is mild and moist. Otherwise, such species as $R$. Lyallii, $R$. insignis, $R$. Godleyanus, and $R$. Buchanani would be amongst the most famous gardenplants of the world. It might be feasible to ship the fleshy rhizomes of $R$. Lyallii (the mountain-lily) during the winter. These, if potted or grown in a shady part of the garden, should flower quite well. But, in all likelihood, the plants would not be of further use. Be this as it may, such a lovely flowering-plant, if it could be procured cheaply-and that would depend altogether upon the demand-might well become a feature of the spring garden, coming in a little after the daffodils.

\section{(20.) The Species of Raoulia.}

No plants in any flora are better suited for rock-garden purposes, occupying a similar place to the saxifrages, than are the different species of Raoulia, a remarkable genus confined to New Zealand. Leaving out of consideration the huge cushion-plants, briefly dealt with below, the species suitable for garden purposes are those which form circular green or silvery mats, or low cushions. These plants, when once established, can be increased to any extent by means of 
small rooted pieces. The most important species are-Raoulia australis (silvery); $R$. lutescens (silvery and extremely compact); $R$. tenuicaulis (more open than the above); $R$. subsericea (rather moss-like); $R$. glabra (much as the lastnamed); $R$. Monroi and $R$. Beauverdii. $R$. lutescens is extremely conspicuous when covered with its tiny, sweetscented, yellow flower-heads.

Small pieces of the coral-like cushions of $R$. eximia, the celebrated "vegetable sheep," can be cultivated as potplants in a greenhouse. This might be thought the most ridiculous treatment for a plant which grows upon solid rock in the alpine belt, but it is the only method that so far has succeeded in keeping the plant alive for any length of time. Seen from a distance, the huge white woolly cushions, dozens of them in close proximity, look not unlike a flock of sheep at rest, and the story goes that they have been mistaken for such by the shepherd-a quite likely happening. Another form of vegetable sheep belongs to the genus Haastia ( $H$. pulvinaris), and the wonderful cushions of these are even more woolly and sheep-like. Other species of Raoulia build smaller but similar cushions, one of which is green. These cushions are really shrubs, the stems of which, hugged by the small woolly leaves, are pressed tightly together. As the plant grows, much of the older parts turns into peat, which holds astonishing quantities of water. The young branches put down roots into this peat, so that the plant lives for the most part upon its dead self. A fine example of the vegetable sheep brought from Southern Alps can be seen in the exhibit of the New Zealand Government.

\section{FERNS.}

About I40 species of ferns grow wild in the New Zealand botanical region, while for garden purposes many well-marked varieties are also available. The species differ greatly in their characteristics. Taking stature, there is a tree-fern $60 \mathrm{ft}$. high, and moss-like plants less than $I$ in. above the ground. The leaves may be $\frac{1}{8}$ in. thick, and able to withstand the most furious gale or parching heat, or they may 
be so thin as to shrivel up rapidly when taken from the saturated atmosphere of their forest home. Again, in habit, some are tufted, others have far-creeping stems, and others climb high up the lofty trees or live perched upon their boughs. There is obviously then a rich material upon which to draw, so that ferns may be found suitable for almost any condition, whether of extreme moisture or dryness. All the same, it must be borne in mind that the majority are forestdwellers, and that in consequence they demand a moist atmosphere, shade, and absence of wind. Positions of this kind in most localities are not available in ordinary gardens, so that our ferns must be grown either as pot-plants for the cool greenhouse, the conservatory, or the room, or special structures may be erected as ferneries where the necessary conditions are provided.

Ferns are easier to ship for long distances than floweringplants. Tree-ferns, their leaves cut off, travel admirably, even in the hold of the vessel; the constant moisture-demanding filmy ferns can be sent for a certainty in tins by parcelspost; small specimens of Todaea superba and $T$. hymenophylloides should be forwarded in a similar manner, and larger ones, if the leaves are to be preserved, in close boxes; in fact, a good many ferns appear to travel excellently in this manner. Ferns with small trunks may be treated similarly to tree-ferns, but they should be placed in boxes with some moist Sphagnum. Finally, Wardian cases, as already mentioned, may be used for purposes of shipment.

\section{(a.) Ferns suitable for growing in the Open without Special Shade.}

Ferns of this class have either thick or stiff leaves or moisture-containing rhizomes. The following are suggested: Paesia (Pteris) scaberula; Doodia media; Asplenium obtusatum; thick-leaved erect A. flaccidum; Polystichum Richardi; Cyclophorus (Polypodium) serpens.

\section{(b.) Ferns suitable for growing in Shady Moist Sheltered Parts of the Garden.}

Cyathea dealbata (silver tree-fern); C. medullaris (black treefern); Dicksonia fibrosa (8-20 ft. high); D. squarrosa $(6-8 \mathrm{ft}$. high); Leptolepia (Davallia) novae-zealandiae; Adiantum affine, 
A. hispidulum (maidenhair ferns); Hypolepis millefolium (dies to ground in winter); $H$. temuifolia; Pellaea rotundifolia (tolerates a dry position); Histiopteris (Pteris) incisa; Blechnum* discolor; B. Banksii; B. durum; $B$. penna marina, syn. alpina; $B$. capense; $B$. filiforme (high-climbing); $B$. Fraseri (a miniature tree-fern with a stem no thicker than a stout walking-stick); Asplenium adiantoides, syn. falcatum; A. lucidum; A. Hookerianum; A. bulbiferum; Polystichum vestitum; $P$. hispidum; $P$. adiantiforme; Dryopteris (Nephrodium) glabella; Nephrolepis cordifolia; Polypodium tenellum; $P$. diversifolium, syn. Billardieri; any of the species of Gleichenia (these, the remarkable umbrella-ferns, are very difficult to establish in the first instance); Lygodium articulatum (climbing); Marattia traxinea.

\section{(c.) Ferns that can best be grown in a specially prepared Fernery.}

Adiantum aethiopicum; Hypolepis distans; Pteris tremula; Pt. comans; Blechnum Patersoni var. elongata; $B$. vulcanica; $B$. lanceolata; $B$. Auviatile; $B$. membranacea; Asplenium umbrosum; Dryopteris (Nephrodium) decomposita; D. (Polypodium) pennigera; Polypodium pustulatum; P. novae-zealandiae.

\section{(d.) Ferns that demand a Constant Moist Atmosphere, so that they can be grown only under Glass in the Shade.}

All the species of Hymenophyllum and Trichomanes (filmy ferns)-the handsomest of these are $H$. demissum, $H$. bivalve, $H$. pulcherrimum, $H$. dilatatum, $H$. scabrum, H. multifidum, $H$. ferrugineum syn. aeruginosum; T. reniforme (kidney-fern); T. elongatum. Also the exquisite Todaea (Leptopteris) superba (crape-fern), T. hymenophylloides, and the black-leaved Blechnum nigrum.

The New Zealand ferns differ considerably in their degree of hardiness, but this has not been indicated specifically, since, in America, they will be used chiefly for glasshouses and decoration indoors.

* All the ferns here named Blechnum are frequently termed Lomaria. 
By Authority : John Mackax, Government Printer, Wellington.

[ro,000/10/1 $4-17298$ 


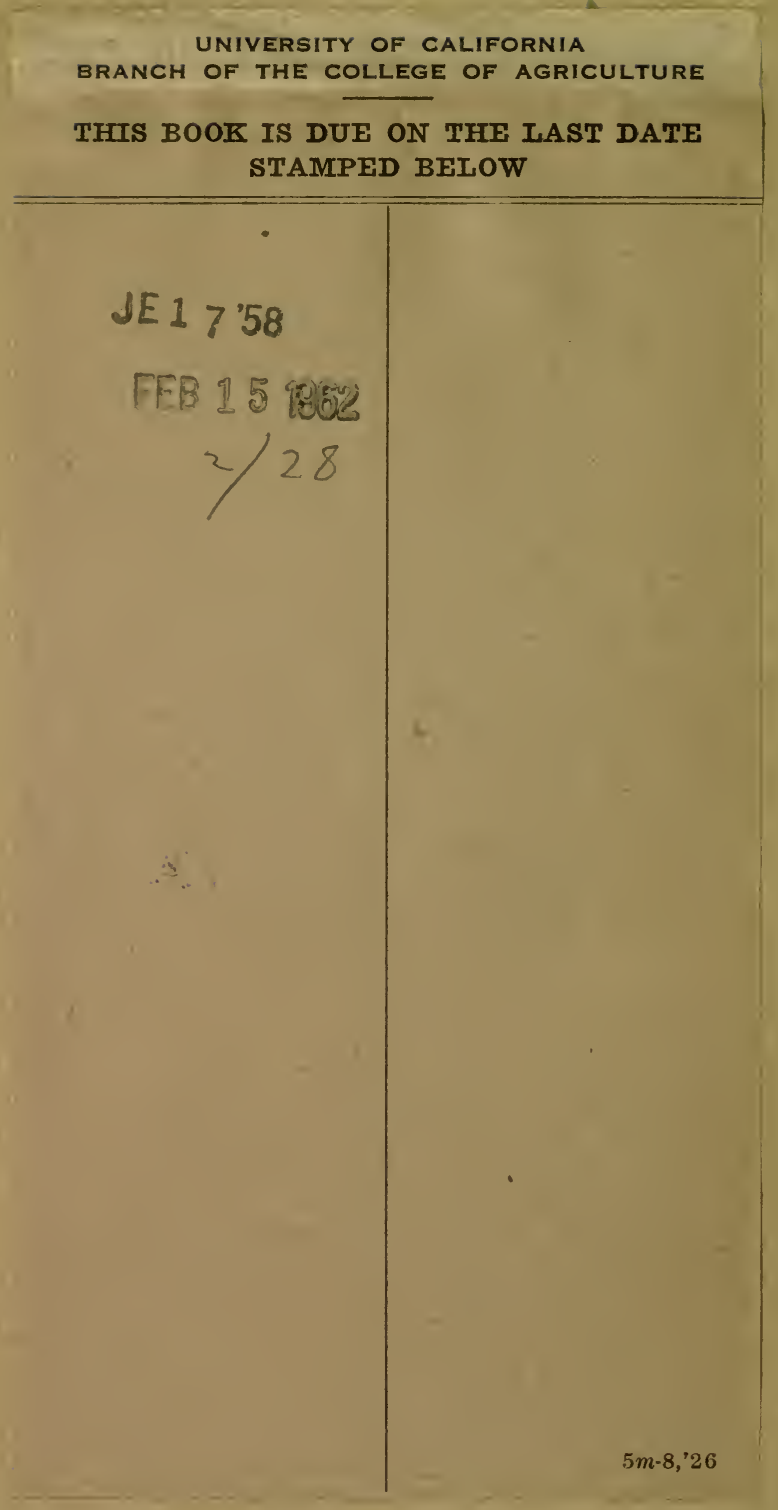


Binder Gaylord Bros. Makers Stockton. Calif. PAT. JAN. 21. 1908
8696

QRL63

New Zearime plants suitable for North American gardens. 
Wha.

$2 x$

20

r.

$\left.y^{3}\right)^{x} x^{3}$

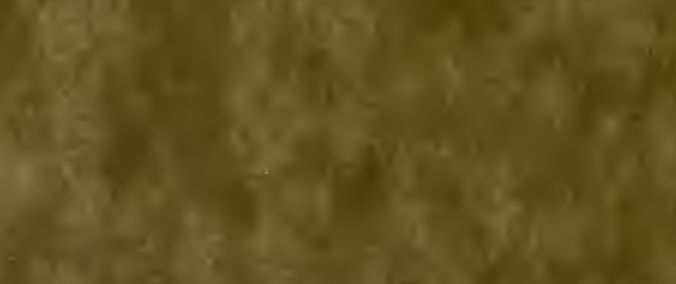

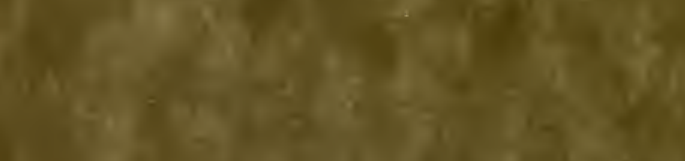

18

Wensto,

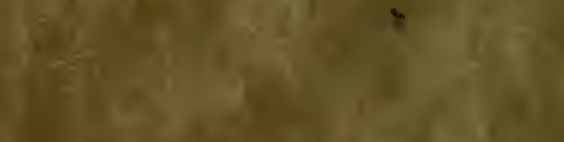

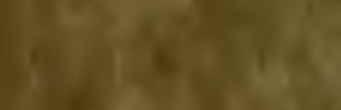

$(2,19$

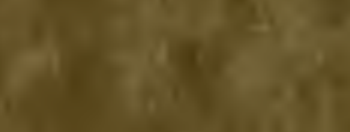

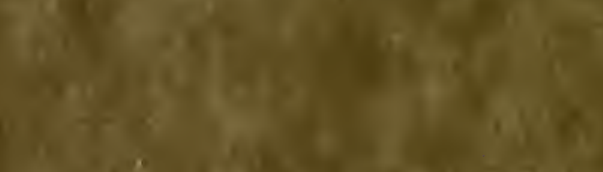

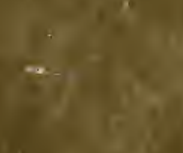

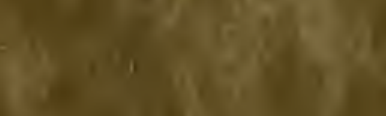

$=$

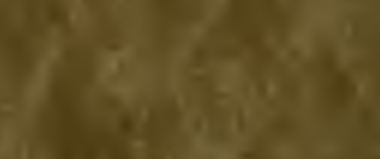

$x_{1}+y^{2}+1=$

1.

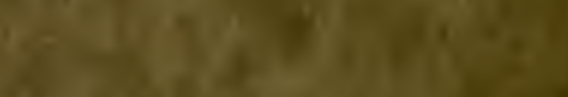

tent

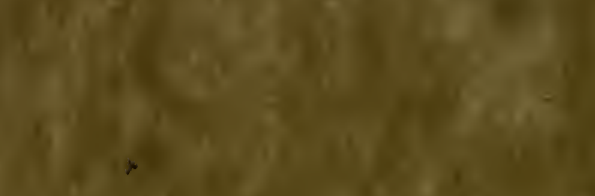

